\title{
Correction to: CRISPR-Based Diagnosis of Infectious and Noninfectious Diseases
}

Somayeh Jolany vangah ${ }^{1 \dagger}$, Camellia Katalani ${ }^{2 \dagger}$, Hannah A. Boone ${ }^{3 \dagger}$, Abbas Hajizade $^{4}$, Adna Sijercic ${ }^{3}$ and Gholamreza Ahmadian ${ }^{1 *}$

\section{Correction to: Biol Proced Online 22, 22 (2020)}

https://doi.org/10.1186/s12575-020-00135-3

In the original publication of this article [1], there was an error in the article, the authors opted to correct the last name of co-author Hannah Abigail Boone from Booneh to Boone. The original article has been corrected.

\author{
Author details \\ 'Department of Industrial and Environmental Biotechnology, National \\ Institute of Genetic Engineering and Biotechnology (NIGEB), Tehran P.O.BOX: \\ 14155-6343 Iran. ${ }^{2}$ Department of Plant Biotechnology and Agricultural \\ Science, Sari Agricultural Science and Natural Resource University, Sari, Iran. \\ ${ }^{3}$ Department of Genetics and Bioengineering, International Burch University, \\ Francuske Revolucije bb, Ilidza, 71210 Sarajevo, Bosnia and Herzegovina. \\ ${ }^{4}$ Applied Microbiology Research Center, Systems Biology and Poisonings \\ Institute, Baqiyatallah University of Medical Sciences, Tehran, Iran.
}

Published online: 07 November 2020

\section{Reference}

1. Jolany vangah S, Katalani C, Boone HA, Hajizade A, Sijercic A, Ahmadian G. CRISPR-based diagnosis of infectious and noninfectious diseases. Biol Proced Online. 2020; https://doi.org/10.1186/s12575-020-00135-3.

\footnotetext{
The original article can be found online at https://doi.org/10.1186/s12575020-00135-3.

* Correspondence: ahmadian@nigeb.ac.ir

'Somayeh Jolany vangah, Camellia Katalani and Hannah A. Boone contributed equally to this work.

'Department of Industrial and Environmental Biotechnology, National Institute of Genetic Engineering and Biotechnology (NIGEB), Tehran P.O.BOX: 14155-6343 Iran
}

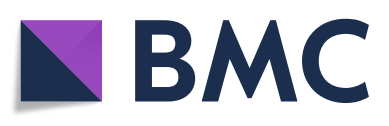

() The Author(s). 2020 Open Access This article is licensed under a Creative Commons Attribution 4.0 International License, which permits use, sharing, adaptation, distribution and reproduction in any medium or format, as long as you give appropriate credit to the original author(s) and the source, provide a link to the Creative Commons licence, and indicate if changes were made. The images or other third party material in this article are included in the article's Creative Commons licence, unless indicated otherwise in a credit line to the material. If material is not included in the article's Creative Commons licence and your intended use is not permitted by statutory regulation or exceeds the permitted use, you will need to obtain permission directly from the copyright holder. To view a copy of this licence, visit http://creativecommons.org/licenses/by/4.0/. The Creative Commons Public Domain Dedication waiver (http://creativecommons.org/publicdomain/zero/1.0/) applies to the data made available in this article, unless otherwise stated in a credit line to the data. 